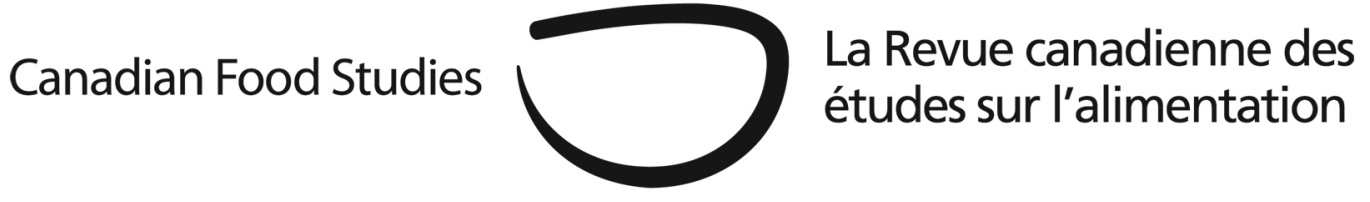

Original Research Article

\title{
Old habits die hard: The need for feminist rethinking in global food and agricultural policies
}

\author{
Andrea M. Collins* \\ University of Waterloo
}

\begin{abstract}
A number of global initiatives designed in recent years address global food security and aim to reduce the vulnerability of small-scale and peasant farmers in the face of expanded transnational investment in large-scale agriculture and land acquisition. While there have been efforts to consider women within such initiatives, global governance institutions often overlook the complex gendered dimensions of food systems alongside agricultural land and labour markets. Although institutions emphasize the need for “women's empowerment”, few policy recommendations have considered its practical application. Indeed, many governance initiatives that address food security or promote land security tend to depoliticize inequalities, which shows the importance of feminist food studies from the perspective of global food and land policy. Integrating a feminist food studies lens to the global governance of food and agriculture allows us to explore the complexities of gendered relations in agricultural practices. A more complete understanding of everyday material, socio-cultural and corporeal experiences within agricultural practices provides a greater understanding of the mechanisms by which gender relations structure food production, land ownership, resource access and governance processes. By using a feminist food studies lens we see a more complete picture of the realities of local resource management and the potential implications for global policymakers such as the World Bank, the Food and Agriculture Organization of the United Nations (FAO) and the United Nations Committee for World Food Security (CFS). Through this framework, I illustrate how feminist analyses
\end{abstract}

*Corresponding author: andrea.collins@uwaterloo.ca 
challenge conventional approaches to gender in global policymaking related to food and agricultural production.

Keywords: gender, food, land, global governance, agricultural investment

\section{Introduction}

The operations of global food and agricultural systems have become a key focus of several international institutions, prompting a series of initiatives designed to address global food security concerns while also addressing the vulnerability of small-scale and peasant farmers to expanding transnational investment in large-scale agriculture and land acquisition. Wise (2015) suggests that the institutions and policies enacted in the wake of the 2007/08 food price crises were inadequate for addressing the state of the food system and questions whether policies genuinely put small-scale farmers, particularly women, first. In the context of these concerns, a feminist food studies lens on the challenges of global food security is well-positioned to delve into these questions, highlighting the gendered dimensions of these imbalances of power, both in communities and in families, as well as the everyday experiences of small-scale, subsistence, and peasant farmers. Feminist food studies scholarship is thus vital for providing a more nuanced understanding of the gendered dynamics of food production and consumption, alongside the changes in the global food system that are driving further commercialization and investment in agriculture. However, I also illustrate why changing how global policymakers discuss gender, food, and agriculture remains a significant challenge.

The global scope of women's participation in agriculture is well-documented: though Doss (2014) has dispelled the "stylized fact" that women produce $60-80 \%$ of the food in low-income countries, she nonetheless concludes that the agricultural industry is critical for women across the world. Nearly $80 \%$ of economically active women in the world's least developed countries work in agriculture; worldwide that figure is estimated to be $48 \%$ (Doss, 2014). Yet as governance shifts in favour of large-scale production and new "innovations" in farming technology, a more comprehensive and complex understanding of the everyday experiences of individuals within these systems needs to inform policy-making at the global level. As such, it is crucial to understand the gendered power relations implicit in the governance and practices of food systems - both globally and locally.

Though global governance actors and institutions often recognize the need to address gender inequality within the context of food security, by citing or collaborating with key feminist experts and scholars on matters related to food and agriculture ${ }^{1}$, gender often remains a marginal consideration in many global food security and agricultural initiatives, with limited

\footnotetext{
${ }^{1}$ For example, scholars studying gender and agriculture such as Bina Agarwal, Elisabeth Daley, and Cheryl Doss, have contributed to and/or have been cited within institutional documents produced by the FAO and the World Bank. See FAO 2013, World Bank 2012 and World Bank et al 2015.
} 
implementation at the national level. By adding the terms "women" and "gender" into various phrases and clauses, these initiatives appear to be inclusive. Yet, efforts to include gender in such a superficial way risk reducing gender inequality to a technical fix, and neglect the complex social structures and overlapping oppressions that also must be addressed on the ground (Parpart, 2009). Systems of gender inequality are thus unexamined in the absence of a comprehensive understanding of the gendered dimensions of contemporary food and land systems and the strategy needed to address them. Women and food security advocates at the global level call for more attention to women's formal, informal and care labour; structures of discrimination; and the need to "incorporate women's real life experiences," in the collection of data about food systems (CFS, 2017, p. 2).

Feminist food studies scholarship does precisely this: it highlights how people have gender-differentiated experiences within the global food system and articulates how relationships with food and food production can "reproduce, resist and rebel against gender constructions," (Avakian \& Haber, 2006, p. 2). I argue that a feminist food studies approach complements the work of feminist scholars who have identified the need to understand gender structures in the global economy and development policies. Feminist food studies provide a lens to conceptualize the ways in which our everyday relationships with food and food systems are gendered, complementing our understandings of global food systems. When the feminist food studies approach — with its focus on the material, socio-cultural and corporeal dimensions of food politics - is combined with broader critiques of the global food system, it is possible to develop clearer paths forward to address food access and security issues. A nuanced appreciation of the competing demands on women in productive and reproductive labour, as well as socio-culturally determined roles and responsibilities alongside the challenges of inclusion in decision-making, clearly identifies locally specific obstacles to food security issues and the ways in which they may be addressed.

I survey how several global food and agricultural governance initiatives have addressed gender since 2008, and evaluate each based on a close examination of each initiative's documentation and responses from civil society organizations. First, I consider the Voluntary Guidelines on the Responsible Governance of Tenure of Land, Fisheries and Forests in the Context of National Food Security (VGGT), produced by the reformed multilateral United Nations Committee for World Food Security (CFS). Second, I examine two sets of principles for responsible agricultural investment, one produced by the World Bank, in partnership with the Food and Agriculture Organization of the United Nations (FAO), the International Fund for Agricultural Development (IFAD), and the United Nations Conference on Trade and Development (UNCTAD), and the second by the aforementioned CFS. Finally, I examine the New Alliance for Food Security and Nutrition, a public-private partnership (PPP) designed to coordinate between the G8 (now G7) countries, 10 African countries, and national and international corporations to encourage greater foreign investment in African agriculture. Though distinct, all three modes of governance pledge to consider gender, and specifically smallscale women farmers, but also often promote commercialization and investment in agriculture. 
A robust feminist food studies lens-bolstered by considerations of gender dynamics at multiple levels and spaces - enables us to explore how global agricultural policies may push an agenda of commercialization at the expense of a comprehensive gender equality agenda.

Within several mechanisms of global food and agricultural governance, there is a tendency to frame gender equality as the inclusion of women, often with limited attention to the broader structures of gender inequality and gendered practices related to food production and reproductive work. This tendency to "add women” aligns with old habits in global governance and policy-making. At the same time, if we look at how gender is perceived and articulated in these mechanisms, we can also see openings for change and influence, with opportunities to create genuinely empowering spaces (Arora-Jonsson, 2014; Prügl, 2014). As explored below, there is particular cause for optimism as we look more closely at the support for change from within certain institutions and sets of recommendations, specifically the work done within the FAO and the CFS, where civil society organizations can play an active role in shaping policy outcomes. Here we can also see opportunities to bring the findings of feminist food studies scholarship in conversation with global policymaking.

\section{Feminist examinations of food security and production}

While food security and food sovereignty are a high priority for a number of global actors, and there have been efforts to acknowledge gender inequalities, there has been a rather limited conceptualization of gender inequality. Though there is a significant shift in the way that institutions such as the World Bank articulate their goals to include the social dimensions of development projects (Bergeron, 2003), there are still shortcomings in the way that institutions anticipate the gendered dimensions of new efforts to address food insecurity. Though global institutions such as the FAO and the World Bank regularly report on the important role of women within agriculture, rarely is the full complexity of gendered experiences within food production and agricultural land politics incorporated into global governance mechanisms around agricultural investment and food security. Though we see engagement with gender-aware scholarship in more comprehensive documents such as the Gender and Agriculture Sourcebook (World Bank, FAO, \& IFAD, 2015), at the same time these efforts are not often connected to critiques of global structures of agricultural trade and investment (Collins, 2018).

In contrast, feminist food studies implore us to consider the "daily lives of ordinary people” (Avakian \& Haber, 2006, p. 2). Allen and Sachs (2006) note that feminist food studies helps us to examine connections between gender and the material, socio-cultural, and corporeal dimensions of food, and offer strategies for how we can understand the gender dimensions of productive and reproductive labour, the household responsibilities tied to food, and the gendered dimensions of food consumption. Combined with gender and development perspectives as well as feminist political economy perspectives that inform critiques of the global economy of 
agriculture, feminist food studies scholarship further highlights the experience of women within these structures.

In the context of global agricultural policymaking, it is essential that scholars, activists and decision-makers consider the contributions of feminist food studies in order to understand the how global pressures driving agricultural change impact the gendered relations of production, reproduction and consumption. To do so requires an understanding of the global economic dimensions of the food system, but also how socio-cultural structures shape divisions of labour, including productive and reproductive or care work. Wichterich (2015) has illustrated how the commitment to "green growth" on the part of states and corporate actors promotes shifts in agricultural production. The renewed focus on privatization and productivity leads to the “devaluation of small-scale agriculture as inefficient and not profitable," which places investors in opposition to local producers and peasants, particularly women, who use common lands for water, energy and food (Wichterich, 2015, p. 80). The phenomenon is also highlighted within the context of large-scale agricultural land deals (Behrman, Meinzen-Dick, \& Quisumbing, 2012). As I will show, productive or reproductive agricultural roles may be difficult to disentangle, where what might be viewed as reproductive household labour may also support productive labour (and vice versa). Several scholars have further considered the performance and reproduction of gender as inextricably tied to foodwork as well as the management of environmental resources (Brady, Gingras, \& Power, 2012; Nightingale, 2006), which pushes us to think beyond the material inequalities tied to farming and other modes of food production. These insights are particularly important considerations when we consider how foodwork and farming overlap, and the potential disruptions that can be introduced through new crops, new technologies, and new modes of farming.

In the context of global agricultural policies, we can consider how prescribed shifts in agricultural practice have multiple gendered impacts on production, reproduction and consumption. For instance, with the introduction of new agricultural practices or herbicides, women may lose access to "weeds" once used to feed families (Beuchelt \& Badstue, 2013). A feminist food studies perspective allows us to consider how shifts in agricultural practice can shift structures around food production, the divisions of reproductive labour, the consumption patterns of individuals, and an understanding of how identities are formed and shaped by our relations to food and foodwork.

The current state of the global trade in food and agriculture requires an analysis that connects material, socio-cultural and corporeal relationships with food. Large-scale land acquisitions, expanded agricultural trade, growth in agricultural technologies, and efforts to alleviate malnutrition all shape our everyday experiences with food. Moreover, each aspect has gender-differentiated dynamics and effects. Where global governance projects recommend the development of land markets, the expansion of agricultural labour markets, and the introduction of new agricultural technologies and farming methods to increase productivity, these projects enter into the complicated social relations that shape our food systems. It is here where a genuine need exists to bridge the insights of feminist food studies scholarship into policy development 
and implementation to understand the possible social impacts of such changes and the opportunities for resistance and change. As such, I explore the connections between gender and agricultural labour highlighting the interplay of both productive and reproductive gender roles in shaping agricultural labour practices. I follow with a related consideration of how socio-cultural norms and governance practices shape agricultural land access and control, a fundamental consideration in food security. In these surveys, I focus on the material, socio-cultural and political dimensions of agricultural practices that are shaped by global shifts in agricultural policy and practice.

\section{Gender, labour, and food security}

The challenges faced by women in agricultural work - whether on a family farm, communal lands, in agricultural labour markets, or elsewhere-are not new: women have long faced social constraints "that limit their capacity to contribute to agricultural production," (Rao, 2012, p. 84). In particular, women often face discrimination in access to productive resources: women-headed households frequently have reduced access to agricultural inputs and lower productive inputs as agricultural extension programs largely target male farmers (Agarwal, 2014). Further, the divisions of productive and reproductive labour within households mean women are responsible for time- and/or labour-intensive work, such as water collection or hand weeding crops. Deeply ingrained power imbalances within households, gender gaps in access to agricultural inputs, and women's limited access to secure land rights result in lower productivity, and ultimately less food security for women farmers (Agarwal, 2014).

Despite recognition of the above-mentioned social obstacles and opportunities for resolution, for example, through targeted agricultural extension services, global actors also continue to promote economic empowerment for women via expanded opportunities in formal paid agricultural labour. In discussions of agricultural investment, the promise of job creation and women's participation in labour markets is often hailed as boon to gender equality, as well as an important source of productivity (FAO et al., 2010). There are a number of international projects that valorize the inclusion of women in labour markets as a feminist project and use feminist languages towards profitable ends (Roberts, 2014).

Yet, there are doubts about the "empowerment" of women that should accompany expanded industrial agricultural production and shifts to cash cropping in low-income countries (Mbilinyi, 2012). There are persistent barriers to women's equal participation in labour markets. Women "face wage discrimination in rural labour markets; and they are also more likely to be in part-time, seasonal, and /or low-paying jobs when engaged in wage employment,” (Rao, 2012, p. 84). The shifts to formal employment are not frequently accompanied by shifts in socio-cultural expectations about household responsibilities, food provision, or women's control of monetary resources. Household disputes and the potential for domestic violence over control of resources if women have stronger economic positions in households may then occur (Daley, 2011). Thus, 
there is a need to also consider corporeal experiences with violence where household economies are disrupted because of agricultural shifts.

As a result, arguments in favour of expanding women's access to paid agricultural work are often not followed by an acknowledgement of how deeply held societal gender norms might be, how they manifest in labour markets and individual experiences, and how difficult they are to challenge. While increased women's employment in agricultural industries should not necessarily be dismissed as exploitative, there are a number of social changes that must occur concurrently to prevent such exploitation. As discussed below, such attitudes also inform the expansion of agricultural investment for food security.

\section{Gender and agricultural land access}

In addition to the gendered divisions of labour and unequal access to inputs, there are also gendered divisions in agricultural land access across regions targeted for agricultural investment, particularly in sub-Saharan Africa and Southeast Asia. Though rural women are estimated to undertake at least half of the agricultural labour in sub-Saharan Africa, they rarely have sole ownership over or control of the land itself (Daley, 2011). Instead, in some places, rural women's claims to land are embedded in social practices and kinship relations, including marriage (Whitehead \& Tsikata, 2003). In patrilineal societies in rural East Africa, for example, where communities protect clan land via patrilineal inheritance practices, it can be difficult for poorer rural women to claim land as their own without fear of alienation from their communities (Koda, 2000). As a result, the challenge of recognizing socio-cultural traditions in land governance while also promoting gender equality has proven to be difficult under legal pluralist models (Agarwal, 1994; McAuslan, 2010; Whitehead \& Tsikata, 2003). These challenges emphasize the need to understand context-specific gender dynamics related to agricultural production and reproduction, including familial patterns of inheritance and expectations about who performs which tasks.

Recently, shifts toward commercial agricultural investment also focused attention on the gender-differentiated effects of these investments, particularly around the issue of land rights and access. Daley's (2011) review of the gendered impacts of commercial pressures on land shows how women continue to suffer from systemic discrimination related to land access and ownership, discrimination in socio-cultural and political relations, and income inequality. Similarly, women have been excluded from participation in agricultural land deals: the absence of formal or informal land rights, the lack of representation in local decision-making, or the social norms that restrict women from exercising their legal rights, impact women's ability to participate in land markets (Behrman et al., 2012). Thus, there are concerns about the ability of communities to continue to meet their food and resource needs without the active and meaningful participation of women to articulate their modes of land use for reproduction and consumption. 


\section{Inclusion, participation and decision-making}

The dynamics around decision-making and agricultural land use speak to the broader importance of meaningful political inclusion and participation. Multiple forms of governance and social discipline intervene in land politics and community-based decision-making, which can silence women's voices even in progressive legal frameworks (Verma, 2014). Recommendations to shift to customary forms of land rights need to be negotiated carefully to ensure that patriarchal or patrilineal traditions do not negatively affect women's agricultural land access (Whitehead \& Tsikata, 2003). At the same time, recommendations to shift to marketization must be careful not to reduce social protections that might be afforded through customary practices or the state (Fraser, 2013). In both cases, as Fraser (2013) notes, the goal for feminists should be connected to the goal of emancipation.

As discussed below, many global institutions and partnerships for food security focus on inclusion and participation of women as a key mechanism by which gender inequality can be addressed. In some cases, the focus is on enhancing women's roles in decision-making over land and other agricultural resources, and in others, a focus on inclusion in land and labour markets. For feminist scholars, such efforts to improve inclusion ring hollow where they do not also consider the quality of participation of women and other marginalized groups and the social structures that prevent full participation and inclusion (Carella \& Ackerly, 2017). Approaches to gender equality need to do more than improve gender parity in representation, and must also challenge social structures of oppression in various arenas (Carella \& Ackerly, 2017).

Feminist food studies scholarship further highlights these everyday experiences of women, and how meaningful participation and the enjoyment of rights might be limited by the burdens of care and foodwork, as well as other productive and reproductive roles women and men are expected to fulfill. Importantly, each dimension must be considered within the broader context of food production, household and care work, and meaningful participation in decision-making. The combination of all factors - and others that emerge in locally specific analyses - create a complex picture of agricultural production that merits consideration in broader geopolitical affairs.

\section{Looking at global food and agricultural governance}

Despite these highly contested socio-political challenges, global efforts to improve food security describe gender equality and inclusiveness in relatively apolitical terms. Rather than considering the broader structural constraints imposed by gender roles and expectations, many initiatives still attempt to add women to projects designed to improve food security. Such strategies are unlikely to have success in genuinely improving gender relations or fully responding to the food security needs of peasant and small-scale food producers. It is only where institutional experts have recognized the broader societal challenge posed by patriarchal social and political structures do 
we see movement towards a more comprehensive strategy to address gender inequality in food security through an appreciation of its socio-political dimensions.

Each of the initiatives discussed below recognize gender equality as an important dimension of reform. This is deserving of praise, especially where gender issues have been omitted from other efforts to govern critical environmental resources (Arora-Jonsson, 2014). However, there are varying levels of success in how accurately these initiatives reflect the challenges of food security and land reform or describe long-term trends. Though the effort to establish best practices for the recognition of land and resource tenure rights is a crucial step, other discussions at the global level suggest room for improvement. When initiatives move away from a contextualized understanding of social and political structures and towards the simplified “adding of women," global governance mechanisms offer few details on how to pursue food security with meaningful attention to gender. In doing so, these mechanisms practice the same old habits of global governance more broadly.

\section{Breaking the habit? The Voluntary Guidelines on the Responsible Governance of Tenure of Land, Fisheries and Forests (VGGT)}

The recently reformed UN-CFS ${ }^{2}$ laudably mainstreamed gender throughout its first major set of food security guidelines, the VGGT. Activists and scholars alike praised the CFS for its passing of the VGGT in 2012 (McKeon, 2015). Responding to the ripple effects of the food and financial crises, the CFS attempted to address concerns over the land and resource rights of peoples who do not have formal titles or legally recognized rights to land, but who nonetheless rely on land and resources. The VGGT encouraged states to recognize customary rights to land, forests, and fisheries in order to protect people and their livelihoods from state expropriation of land or largescale land deals for commercial agricultural development. At the same time, the VGGT also implored states to recognize, protect and promote the rights of women within land governance and land titling. Mainstreamed throughout the VGGT are calls to pay attention to the gendered impacts of policy decisions, aligned with the goals of the gender mainstreaming project. It also encourages "effective participation" of all people in traditional institutions, "including in the case of collective tenure systems,” (FAO, 2012, p. 14).

It is a significant achievement that gender is so thoroughly integrated into the VGGT; most clauses do contain some reference to consider gender. However, the VGGT only briefly acknowledges the potential for tensions between the recognition of traditional customary rights and the promotion of gender equality (Collins, 2014). The VGGT recognize the various ways in which women and girls might be excluded from land and resource rights, but do not fully engage with these challenges, particularly where they might conflict with traditional patriarchal practices. As noted above, this has long been a concern of scholars of agrarian change and land issues, who have noted that a "re-turn to the customary" modes of land governance favoured in

\footnotetext{
${ }^{2}$ See McKeon (2015) for a discussion on the reformed UN-CFS.
} 
some regions risk undermining pushes for gender equality (Whitehead \& Tsikata, 2003, p. 67). Such a gap in the VGGT further highlights the limits of gender mainstreaming that does not describe gender inequality beyond gender gaps in representation. Without a broad view of the obstacles to gender equality in land rights, the VGGT alone offers little advice for those seeking to enact reforms that protect traditional modes of local land governance and advance gender equality in a practical and meaningful way. In the absence of a more systematic view of the constraints and obstacles to gender equality in both formal-legal and customary land systems, including socio-cultural norms that shape gender divisions of labour and patterns of resource access as well as participation in governance, there is little reason to expect lasting, systemic change that improves the security of agricultural land.

Fortunately, the FAO also produced more practicable supplemental documents for implementing the VGGT, providing important insights on strategies for advocacy and implementation. In Governing Land for Women and Men: A Technical Guide to Support the Achievement of Responsible Gender-Equitable Governance of Land Tenure (FAO, 2013), the FAO advances recommendations for fulfilling the commitments of the VGGT in a way that integrates traditional and customary practices with the advancement of women's land rights. The Technical Guide recommends strategies that explicitly address socio-cultural norms and builds partnerships with local authorities, including traditional and religious leaders to overcome systemic bias.

For example, the Guide warns that gender quotas for representation, while important, are not sufficient to address gender inequalities. The Technical Guide notes that in addition to quotas, women "may also need training and support for active and constructive engagement" (FAO, 2014, p. 17), while organizers should ensure "that meetings are held at times that are generally convenient for women,” (FAO, 2014, p. 36), and broader engagement with and recruitment of customary leaders and the community are necessary to advance gender equity. The Technical Guide further highlights the role of media in raising awareness, and the importance of identifying gender equitable practices that already exist in local customs. These tools and practices, if enacted thoughtfully and with adequate funding from states, international institutions, and donors, could form the basis of a more robust and equal land governance system founded within existing norms and practices.

The VGGT and the FAO Technical Guide together create important global policy space for a more gender equitable food and land security paradigm. These efforts offer genuine opportunities for a progressive gender equality agenda, which need to be identified within circles of global governance. These spaces in which new progressive visions can be built are important, particularly as it supports the activists and legal reformers who must do the grassroots work in each local context (Arial et al., 2012). However, despite this success in the efforts to establish norms and best practices around land governance, other global food security initiatives often do not create similar opportunities. As illustrated below, other global mechanisms to address food security have tended to adhere more closely to an "add women and stir" approach, neglecting attention to-and possible solutions for-broader gendered socio-political dynamics. Instead, we 
see an emphasis on further commercialization, with a reliance on global food and agricultural policies that include references to gender equality, but do not consider the everyday experiences of gender relations within agricultural practice.

\section{Establishing principles for responsible agricultural investment}

Strategies to promote more responsible agricultural investment practices often make explicit reference to the role of women in agricultural practice, including land and resource management. References to gender or gender-based differences in these initiatives frequently emphasize the efficiency gains from including women in agricultural investments as well as the potential for “empowering” women through participation in land and labour markets (Collins, 2016; Cornwall \& Rivas, 2015). Despite some important differences, both the World Bank-led Principles for Responsible Agricultural Investment (PRAI) and the CFS's Principles for Responsible Investment in Agriculture and Food Systems (RAI) tend to overlook the complexity of gender in the management of agricultural resources and food security. The emphasis is on the inclusion of women in land and labour markets rather than also considering the social, cultural, and political dimensions of gender relations. Feminist food studies scholarship draws attention towards dimensions beyond the material experiences in land and labour markets.

Establishing “responsible agricultural investment” practices became a priority for the World Bank, FAO, IFAD, and UNCTAD following the 2007-2008 food and fuel crises. These institutions created the PRAI in 2010, which faulted poor governance mechanisms for the risks associated with increased commercial interest in agricultural land. While recognizing that investment can result in the displacement of people, the undermining of rights, reduced food security, and the loss of land access among several other risks, the PRAI also emphasizes the desirability of agricultural investment in low-income countries and the potential of benefits for all individuals (FAO et al., 2010). In terms of the benefits to women, the PRAI suggests that women can boost household food security by obtaining jobs created by new agricultural investment projects. The PRAI also recommends that states and investors hold meaningful consultations, paying special attention to women and marginalized populations.

While such measures are reasonable, important dimensions of food and land security that are shaped in part by gender relations are missed. Even if large-scale agricultural projects are successful in creating jobs for local populations, rural women may be less likely to obtain skilled jobs with higher pay, and could be marginalized into precarious, dangerous, and low-paying work, if they are hired at all (Behrman et al., 2012). Evidence suggests that rural women in lowincome areas tend to take on precarious plantation work as less skilled labourers; they are often paid less and are underrepresented in permanent, office-based work (Tsikata \& Yaro, 2014). In addition, if women do take on employment, this could create additional burdens on productive and reproductive activities, including subsistence agriculture, childcare, and foodwork. These burdens may undermine household food security and nutrition without appropriate support for shifts in labour patterns. And though states, corporations, and local communities may aspire to 
inclusive and meaningful consultations, achieving such outcomes is a long-term process, requiring substantial political, financial and time commitments. Relying on local traditional or customary bodies may also exclude traditionally marginalized groups, particularly where women's land claims threaten to upset community land ownership patterns (Tripp, 2004). As noted above, women claiming rights to communal land may contradict long-standing social practices, and transforming governance processes without also considering this is unlikely to produce meaningful inclusion.

Likewise, the CFS RAI Principles, though an improvement upon the PRAI in some respects, also appear to equate women's empowerment to the inclusion of women in existing market practices. Criticism from civil society organizations noted the RAI Principles’ limited attention to gender inequality and indeed, the RAI Principles suffer from a limited consideration of what women's empowerment could look like in the context of agricultural investment (Collins, 2016). For instance, La Via Campesina (2014) argues that the RAI Principles make no significant advancement on gender discrimination. Though "empowerment" as a term remains undefined in the RAI Principles, appeals to developing "human resource capacity" and "promoting their access to resources and inputs" appear to tie the concept of "empowerment” to market participation and productive labour. Specifically, Principle 3, "Foster Gender Equality and Women's Empowerment,” advises that responsible agriculture investment will: “[ensure] that all people are treated fairly, recognizing their respective situations, needs, constraints, and the vital role played by women," "[eliminate] all measures and practices that discriminate or violate rights on the basis of gender,” “[advance] women’s equal tenure rights,” and “[adopt] innovative and/or proactive approaches... to enhance women's meaningful participation in partnerships, decision-making, leadership roles, and the equitable sharing of benefits,” (CFS, 2014, p. 13). Unfortunately, the RAI Principles do not provide additional detail on the types of social and political obstacles that communities face in identifying and overcoming discriminatory practices, pursuing gender equal land ownership, and establishing such meaningful participation. Though the RAI Principles advise improving access to resources, there is not broader recognition of the social dynamics that work in tandem with economic inequalities.

Though we should not be hasty to dismiss these efforts to address gender in these sets of principles, there are limits to incorporating “women” or "gender” into the governance of agricultural investment without more appreciation of systemic gender inequality and the everyday experiences of women in agriculture. Expanded income opportunities may indeed be empowering, or even emancipatory, for some women, though there are still important caveats that must be made surrounding shifting labour roles, household relations and control of resources (Behrman et al., 2012). Likewise, the goal of enhanced political participation for women in the RAI Principles is commendable. Both the PRAI and the RAI Principles recognize the inherent value of addressing gender gaps in inequality.

Yet the over-arching challenge remains that neither of these mechanisms to promote responsible agricultural investment address the socio-political nature of promoting gender 
equality in practice. For instance, many countries have already legislated equal land rights for women and several have also mandated gender quotas in national and local decision-making to little effect (McAuslan, 2010). Moreover, gender equality in agricultural investment policies tends to be reduced to inclusion, without recognition of the broader social shifts that could also occur. Increased marketization of land and labour may also introduce new gendered vulnerabilities if social protections are also removed (Fraser, 2013). Further, we increasingly appreciate the links between the performance of gender and agricultural responsibilities and foodwork. Understanding shifts in divisions of labour may unsettle the production of gendered subjectivities, which can have detrimental social effects (Nightingale, 2006). A sustained political commitment matched by the financial resources to advocate for systemic and societal change is necessary, rather than recommendations that only focus on reforms to legal structures.

As a result, the few mentions of women and gender within these sets of principles illustrate that there is still opportunity to actively engage with the role of gender relations in shaping the everyday experiences of production and reproduction, or the likely differentiated socio-economic impacts of broader shifts in patterns of agricultural production. Without taking into consideration the pervasiveness of gender roles in the structuring of land and labour markets, these principles can advance ideas about equality, but are not yet positioned to provide definitive guidance on the means to achieve it.

\section{The New Alliance for Food Security and Nutrition}

Another challenge lies ahead as we consider more than just the multilateral institutions that focus on food, agriculture and development. Efforts to address global food insecurity increasingly include corporate actors in order to fund agricultural projects, often in partnership with states and development agencies. Thus, in addition to global regulatory efforts launched by the global institutions discussed above, we must also consider transnational efforts to influence agricultural practices and policies in partnerships with private actors. Launched by the United States at the G8's (now G7) annual summit in 2012, the New Alliance for Food Security and Nutrition pledges to "lift 50 million people out of poverty" by 2022, in part by mobilizing private capital investments in agriculture across ten African states in partnership with the G8 countries (White House, 2012). The New Alliance has Cooperation Frameworks in place with each of its 10 African partner countries, which specify goals for both public and private partners, including multinational corporations (MNCs), such as Unilever and Monsanto. The goals of the Cooperation Frameworks are oriented toward higher productivity in export crops and freer agricultural trade, focused on promoting "commercialization, distribution and adoption of key technologies and improved seed varieties,” (White House, 2012). The Cooperation Frameworks also highlight some important policy foundations, such as rights to land and water.

Included in the language of these frameworks are references to improving the capacities of and delivering "tangible benefits" to women and smallholder farmers (White House, 2012). Each of the initial Cooperation Frameworks signed with Ethiopia, Ghana, and Tanzania includes 
exactly the same preface on the need to "deliver tangible benefits to smallholder farmers, including women," but without elaboration on how projects would benefit women or the particular struggles that women face in agriculture. Critics have noted that the New Alliance's focus on trade and agricultural technologies also masks the important role small-scale farmers play in food security (McKeon, 2014). When we further consider that the majority of small-scale and subsistence farmers are women, there are clearly significant questions remaining about how gender differences will factor into New Alliance plans to revolutionize agriculture.

In 2013, the New Alliance Leadership Council recommended broad voluntary actions to improve “women’s economic empowerment” (New Alliance, 2014, p. 29). Under these new measures, New Alliance partners had to undertake more explicit efforts to include and "empower" women in agricultural value chains. The later Cooperation Frameworks also include detailed consideration of women in agricultural practices compared to the original three Frameworks. For example, the Cooperation Framework with Burkina Faso indicates specific goals to provide women smallholders with agricultural inputs and support a women's group producing parboiled rice (New Alliance, 2013). The New Alliance has also since undertaken sex disaggregated reporting and some partnerships have created jobs for women: where data are available, estimates are as high as $40 \%$ job creation benefitting women (New Alliance, 2014, p. 29). The New Alliance sees a need to "address the socio-economic and political barriers to women's participation in agriculture" and highlights the "opportunity to further unlock the potential of women's economic empowerment through New Alliance investments,” (New Alliance, 2014, p. 30).

Despite these recent efforts to address gender concerns within the New Alliance, the projects still face challenges. Though the New Alliance reports creating jobs for women, only 21\% of the smallholder farmers reached by New Alliance projects were women (New Alliance, 2014). And while 14 companies state that women are part of their workforce and/or supply chain, this only represents less than $10 \%$ of the 180 companies involved in the New Alliance (New Alliance, 2014). Further, there appears to be limited monitoring of the New Alliance commitments on gender equality. The 2014-2015 Progress Report does not reference previous recommendations to address socio-economic and political barriers to gender equality, nor new efforts to address the challenge (New Alliance, 2015). There is limited data at the country level on implementation, but some reporting that exists suggests that overall results are mixed, with outcomes for women unclear (Gagné, 2017).

There is a clear challenge going forward, but there are limits to the strategy of promoting gender equality solely via including women in agricultural land and labour markets. Across these Frameworks, there is little or no reference to the predominance of patriarchal norms or patrilineal traditions, and their role in limiting how women farmers might benefit from proposed investment in agriculture. For instance, despite the focus on smallholder farmers in the Cooperation Frameworks, this term would be a misnomer for many rural women African farmers. As noted above, though rural women undertake a great deal of agricultural labour, their formal ownership of agricultural land is often not guaranteed, and access may be granted through kinship relations 
with men (Verma, 2014). As a result, including women under the category of "smallholder farmer" risks overlooking the larger category of women without formal land ownership. The distinction may seem minor, but where compensation and consultations are built around the legal and/or recognized owners of the land, women without formal or customary control over land are likely to be excluded (Behrman et al., 2012). This has already been a significant gap in efforts to negotiate land for agricultural investment in several sub-Saharan African countries (McAuslan, 2010; Tripp, 2004). And as McKeon (2014) notes, the New Alliance may be further driving the large-scale acquisition of land. Indeed, more independent research is required on the outcomes of the New Alliance and the effects in the 10 African partner countries, as well as on similar projects.

In the absence of comprehensive attention to socio-cultural gendered hierarchies, the consideration of gender inequality in the New Alliance frameworks only addresses the gender gap in commercial agricultural labour and land markets, and even then only in very limited terms. The focus on including women into the existing national plans for agricultural development omits the specific experiences of gender relations that impede efforts to address inequality. Though some Cooperation Frameworks indicate a need to define land rights for local populations, these are complicated long-term projects that require attention to the structural factors that restrict gender equality. The proposed shifts in agricultural production may also affect subsistence agriculture and reproductive labour, leaving less space and fewer inputs for locally consumed crops. Moreover, the reorientation of agricultural labour towards cash cropping may have ripple effects on the availability of water, the use of pesticides and changes to the local environment. Without unpacking the presumptions about how farming operates, and adding women as an afterthought, the New Alliance is poised to expand the scale of agricultural investment without meaningful attention to the role that women play in local food production, household reproduction, or a genuine effort to empower women and/or consider gender.

\section{Conclusion}

As illustrated through these cases, global food and land governance mechanisms can take relatively narrow and/or apolitical views of gender inequality and its possible solutions, in contrast to the specificity and detail offered by a feminist food studies approach. Though global governance mechanisms have shifted to include references to gender-a shift that is deserving of recognition - only rarely do global mechanisms consider gender as a broader set of social relations that must be addressed. As noted above, previous efforts to mainstream gender into global policymaking have led many to view gender inequality as a problem requiring a technical fix. In terms of food and land governance, this can take the form of promoting inclusion in land and agricultural labour markets as a solution to gender inequality in productivity, land ownership and income. The efforts to establish responsible agricultural investment, though distinct, each repeat the expectation that the liberalization of land and labour markets and the participation of 
women will be empowering. The New Alliance, though incorporating more attention to gender in the later Cooperation Frameworks, encourages the creation of jobs for women and, in some cases, partners with women in agricultural production. Yet, market participation, land ownership and food production are bound in social practices, gender norms and expectations, and gendered divisions of labour. Addressing these challenges requires close attention to local power relations and experiences to advance meaningful change. There is a risk of reifying gender inequality in failing to recognize where and why women are already disadvantaged.

Fortunately, there are strategies to address gender inequality by recognizing these sociopolitical challenges. Only by adopting more complex views of gender, food and agriculture can we improve the quality of global food and agricultural governance for everyone. As Prügl (2009) argues, in some cases it is not gender mainstreaming that is the problem, but the sidelining of progressive agendas by mechanisms of power. As a result, more critique and engagement is necessary to push for change, and where these institutions recognize the value of gender equality, there are opportunities for greater engagement. In particular, the reformed CFS - supported by the Rome-based UN agencies — has created more space for discussions of gender inequality within the context of food security. The CFS could be well-positioned to advance the agenda of gender equality, provided there is space and support for those who can convey how gender structures food access, agricultural work and nutrition. Feminist food studies scholars and activists have a tremendous opportunity to engage with such global food governance institutions to make the connections between socio-political gender structures and our land and food systems clear to decision-makers and investors. Future research should focus on these opportunities within global governance institutions and agreements. There is a fundamental need for a sustained feminist food studies approach that considers the complex socio-political gender relations in food and agriculture, which might serve as the basis for better food governance at all levels.

\section{References}

Agarwal, B. (1994). A field of one's own: Gender and land rights in South Asia. New York: University of Cambridge Press.

Agarwal, B. (2014). Food sovereignty, food security and democratic choice: Critical contradictions, difficult conciliations. The Journal of Peasant Studies, 6(41), 1-22.

Arial, A., Palmer, D., Vidar, M., Cebolla, J. C. G., Romano, F., \& Shamsaifar, L. (2012). Governance of tenure: Making it happen. Land Tenure Journal, 1, 63-76.

Arora-Jonsson, S. (2014). Forty years of gender research and environmental policy: Where do we stand. Women's Studies International Forum, 47, Part B(0), 295-308. 
Collins, A. M. (2014). Governing the global land grab: What role for gender in the Voluntary Guidelines and the Principles for Responsible Investment? Globalizations, 11(2), 189-203.

Collins, A. M. (2016). "Empowerment” as efficiency and participation: Gender in responsible agricultural investment principles. International Feminist Journal of Politics, 18(4), 559-573.

Collins, A. M. (2018). Saying all the right things? Gendered discourses in climate smart agriculture. Journal of Peasant Studies, 45(1), 175-191.

Behrman, J., Meinzen-Dick, R., \& Quisumbing, A. (2012). The gender implications of largescale land deals. The Journal of Peasant Studies, 39(1), 49-79.

Bergeron, S. (2003). The post-Washington Consensus and economic representations of women in development at the World Bank. International Feminist Journal of Politics, 5(3), 397-419.

Beuchelt, T., \& Badstue, L. (2013). Gender, nutrition- and climate-smart food production: Opportunities and trade-offs. Food Security, 5, 709-721.

Brady, J., Gingras, J., \& Power, E. (2012). Still hungry: A feminist perspective on food, foodwork, the body and food studies. In M. Koç, J. Sumner, \& A. Winson (Eds.), Critical Perspectives in Food Studies (pp. 122-135). Don Mills: Oxford University Press.

Carella, A., \& Ackerly, B. (2017). Ignoring rights is wrong: Re-politicizing gender equality and development with the rights-based approach. International Feminist Journal of Politics, 19(2), 137-152.

CFS. (2014). Principles for responsible investment in agriculture and food systems. Rome: CFS Secretariat. Retrieved from http://www.fao.org/3/a-au866e.pdf.

CFS Chair. (2017). CFS forum on women's empowerment in the context of food security and nutrition - Chair's summary with draft outcomes. Retrieved from http://www.fao.org/fileadmin/user_upload/bodies/CFS_44/MU756_7/MU756_CFS_2017 44_7_en.pdf

Cornwall, A., \& Rivas, A.-M. (2015). From "gender equality" and "women’s empowerment” to global justice: Reclaiming a transformative agenda for gender and development. Third World Quarterly, 36(2), 396-415.

Daley, E. (2011). Gendered impacts of commercial pressures on land. Rome: International Land Coalition. Retrieved from http://www.landcoalition.org/publications/gendered-impactscommercial-pressures-land

Doss, C., Summerfield, G., \& Tsikata, D. (2014). Land, gender, and food security. Feminist Economics, 20(1), 1-23. 
FAO. (2010). “Climate-smart” agriculture: Policies, practices and financing for food security, adaptation and mitigation. Rome: FAO. Retrieved from http://www.fao.org/docrep/013/i1881e/i1881e00.pdf

FAO. (2012). Voluntary guidelines on the responsible governance of tenure of land, fisheries and forests in the context of national food security. Rome: Food and Agriculture Organization of the United Nations. Retrieved from http://www.fao.org/docrep/016/i2801e/i2801e.pdf

FAO. (2013). Governing land for women and men: A technical guide to support the achievement of responsible gender-equitable governance of land tenure. Rome: Food and Agriculture Organization of the United Nations (FAO). Retrieved from http://www.fao.org/3/ai3114e.pdf

Fraser, N. (2013). Fortunes of feminism: From state-managed capitalism to neoliberal crisis. London and New York: Verso.

Gagné, M. (2017). Is private investment in agriculture the solution? An evaluation of the New Alliance for Food Security and Nutrition in Senegal. Ottawa: Food Security Policy Group (FSPG), Canada. Retrieved from http://www.ccic.ca/working_groups/NAFSN_Final_Report.pdf

Jackson, C. (2003). Gender analysis of land: Beyond land rights for women? Journal of Agrarian Change, 3(4), 453-480.

Koda, B. (2000). The gender dimension of land rights: Case study of Msindo Village, Same District. Ph.D. Dissertation. University of Dar es Salaam, Dar es Salaam.

Mbilinyi, M. (2012). Struggles over land and livelihoods in African agriculture. Development, 55(3), 390-392.

McAuslan, P. (2010). Personal reflections on drafting laws to improve women's access to land: Is there a magic wand? Journal of Eastern African Studies, 4(1), 114-130.

McKeon, N. (2014). The New Alliance for Food Security and Nutrition: A coup for corporate capital? Retrieved from http://www.tni.org/sites/www.tni.org/files/download/the_new_alliance.pdf

McKeon, N. (2015). Food security governance: Empowering communities, regulating corporations. New York: Routledge.

New Alliance. (2013). G8 cooperation framework to support the "New Alliance for Food Security and Nutrition” in Burkina Faso. Retrieved from https://newalliance.org/resource/burkina-faso-new-alliance-cooperation-framework 
New Alliance. (2014). New Alliance for Food Security and Nutrition progress report 2013-2014. Retrieved from https://newalliance.org/sites/default/files/resources/New\%20Alliance\%20Progress\%20Report\%20201 4_Print\%20Friendly\%20Version.pdf

Nightingale, A. (2006). The nature of gender: Work, gender, and environment. Environment and Planning D: Society and Space, 24(2), 165-185.

Parpart, J. (2009). Fine words, failed policies: Gender mainstreaming in an insecure and unequal world. In J. Leckie (Ed.), Development in an Insecure and Gendered World: The Relevance of the Millennium Goals (pp. 51-70). Burlington: Ashgate Publishing Company.

Prügl, E. (2009). Does gender mainstreaming work. International Feminist Journal of Politics, 11(2), 174-195.

Prügl, E. (2014). Neoliberalising feminism. New Political Economy, 20(4), 614-631.

Roberts, A. (2014). The political economy of “transnational business feminism”. International Feminist Journal of Politics, 17(2), 209-231.

Tripp, A. M. (2004). Women's movements, customary law and land rights in Africa: The case of Uganda. African Studies Quarterly, 7(4), 1-19. Retrieved from http://asq.africa.ufl.edu/files/v7i4.pdf

True, J. (2003). Mainstreaming gender in global public policy. International Feminist Journal of Politics, 5(3), 368-396.

Tsikata, D., \& Yaro, J. A. (2014). When a good business model is not enough: Land transactions and gendered livelihood prospects in rural Ghana. Feminist Economics, 20(1), 202-226.

Verma, R. (2014). Land grabs, power, and gender in east and southern Africa: So, what's new? Feminist Economics, 20(1), 52-75.

La Via Campesina. (2014). CFS in Rome: The majority of governments remain blind to the challenges of global food security. Retrieved from https://viacampesina.org/en/cfs-inrome-the-majority-of-governments-remain-blind-to-the-challenges-of-global-food-security/

Whitehead, A., \& Tsikata, D. (2003). Policy discourses on women’s land rights in sub-Saharan Africa: The implications of the re-turn to the customary. Journal of Agrarian Change, 3(12), 67-112.

Wichterich, C. (2015). Contesting green growth, connecting care, commons and enough. In W. Harcourt \& I. L. Nelson (Eds.), Practising Feminist Political Ecologies: Moving Beyond the 'Green Economy' (pp. 67-100). London: Zed Books.

The White House, Office of the Press Secretary. (2012). Camp David declaration. Retrieved from http://www. whitehouse.gov/the-press-office/2012/05/19/camp-david-declaration 
World Bank. (2012). World development report 2012: Gender equality and development. Washington D.C.: World Bank. Retrieved from https://openknowledge.worldbank.org/handle/10986/4391

World Bank, Food and Agriculture Organization of the United Nations, and International Fund for Agricultural Development. (2015). Gender in climate-smart agriculture: Module 18 for gender and agriculture sourcebook. World Bank Group, the Food and Agriculture Organization of the United Nations, and the International Fund for Agricultural Development. Retrieved from http://documents.worldbank.org/curated/en/654451468190785156/Gender-in-climatesmart-agriculture-module-18-for-gender-in-agriculture-sourcebook 